\title{
THE SURVIVAL AND GROWTH RATES OF WOODY VEGETATION IN THE MAN-MADE VRACOV BIOCORRIDOR DURING THE PERIOD OF 1993-2007
}

\author{
BOLESLAV JELÍNEK ${ }^{1}$, LUBOŠ ÚRADNÍČEK ${ }^{2}$
}

\author{
${ }^{1}$ Pavlikova 5,664 44 Ořechov \\ ${ }^{2}$ Mendel University in Brno, Faculty of Forestry and Wood Technology, Department of \\ Forest Botany, Dendrology and Geobiocoenology, Zemědělská 3,616 00 Brno, Czech \\ Republic
}

Received: $12^{\text {th }}$ January 2010 , Accepted: $21^{\text {st }}$ July 2010

\begin{abstract}
The first biocorridors were established in the territory of the Czech Republic in the nineties of the $20^{\text {th }}$ century. One of them, planted on a formed agricultural land, was the Vracov biocorridor. This paper deals with the growth and development of trees on two permanent research plots in the period of 1993 to 2007. Repeated inventories of trees as well as monitoring of biometrical parameters were carried out there in both, the tree and shrub layers. The number of trees decreases with the increasing level of stand canopy. Moreover, mean heights and diameters of Quercus robur, Tilia cordata and Cerasus avium were compared. Under the given conditions, the growth of these tree species can be positively evaluated.
\end{abstract}

\section{INTRODUCTION}

There is a surplus of agricultural land in the Czech Republic. One of the options to deal with the situation is to support afforestation of former agricultural land. Within these measures, extensive areas of agricultural land are detached and converted to forest land resources. Of course, data on the growth of trees planted on the former agricultural land are rather sporadic. The first plantings, which were realized on the former agricultural land in the CR, were elements of the territorial system of ecological stability (TSES). In the 70s and 80 s of the $20^{\text {th }}$ century, an idea of a harmonic cultural landscape originated and was later further developed. The landscape was characterized by suitably distributed ecologically more stable near natural ecosystems in destabilized areas known as the design of the TSES (Buček, Lacina 1984). Structural elements of every TSES are biocentres and biocorridors (Buček, Lacina, Míchal 1995). Biocentres are isles of natural landscape making a long-term existence of a certain ecosystem possible, for example a wetland, forest or a species rich meadow. On the other hand, biocorridors are to connect particular biocentres and to make migrations of organisms between the biocentres possible and thus to create a really effective network (Löw et al. 1995, Zimová et al. 2002).

The design of ecological networks is not specific only to the CR. Ecologists throughout the world deal with ecological networks. However, it is necessary to mention that TSES differs from the foreign conceptions. Our TSES creates an integrated, dense network of 
biocentres and biocorridors, which, in addition to migration, ensures also the increase of ecological stability of cultural landscape. On the other hand, ecological networks are designed above all to ensure migration of organisms. In the majority of cases, biocorridors interconnecting reserves and national parks are designed. Nevertheless, these are much wider and longer comparing to our biocorridors (Bennett 2003; Bennett 2004; Fabos, Ahern 1996; Hilty et al. 2006; Jongman, Pungetti 2004).

A biocorridor (biotic corridor) is defined in an implementing regulation relating to the law on the nature conservation and landscape protection No. 395/1992 Coll. as a territory, which does not enable permanent long-term existence for the decisive part of organisms, however, it makes their migration between particular biocentres possible and therefore it creates a network out of separate biocentres. Thus, the biocorriror is, or should be, created on an ecologically important segment of the landscape. Functionality of biocorridors is conditioned by their spatial parameters (length and width), by the state of permanent ecological conditions and by the structure and species composition of biocoenoses.

As a response to the request for increase in ecological stability of the landscape of South Moravia, the first biocorridors were established in this area of the Czech Republic in 1991. Among the first, the Vracov biocorridor was established. Various tree species were used for these plantings. Quercus robur ( Pedunculate Oak) and Tilia cordata (Small-leaved Linden) were used as "skeleton" species. In addition. Cherry, Maple, Bird Cherry, Hazel, Dogwood etc. were planted there. The Vracov biocorridor was used as a model area to evaluate the growth of these species.

\section{MATERIAL AND METHODS}

\section{Material}

The local Vracov biocorridor lies in South Moravia, district Hodonín, cadastral area of Vracov. It is situated next to the main road Kyjov - Veselí nad Moravou, about $2 \mathrm{~km} \mathrm{NW}$ of Vracov. It was established in 1991. Since the time, its tree component has been monitored (Úradníček 2001, 2002, 2004; Selucký 2008). The total length is $1,830 \mathrm{~m}$ and the width is $15 \mathrm{~m}$. It was established in an area free of autochthonous vegetation on arable land. Its target community should be of the forest environment character. In the biocorridor, 4 permanent research plots (PRP) were laid out each of them being $50 \mathrm{~m}$ long and $16 \mathrm{~m}$ wide. In each PRP, there are 8 rows of trees of a mean distance of $2 \mathrm{~m}$; row spacing is $1-1.6 \mathrm{~m}$ depending on the tree species. To evaluate the growth of selected tree species PRP 3 and PRP 4 were used. From the climate point of view, the biocorridor is situated in the warm region T4, which is the warmest region within the CR. Weather is remarkably warm, moderately to slightly humid (mean annual temperature at the Kyjov and Bzenec stations is $9.2^{\circ}$ and $9.0^{\circ} \mathrm{C}$, respectively). The mean annual precipitation is $569 \mathrm{~mm} /$ year. Higher humidity is caused by the vicinity of the windward slope of the Carpathians. The length of the growing season fluctuates around 165 days per year.

The PRP 3 was established at the distance of $80 \mathrm{~m}$ from the northern part of the biocorridor or $85 \mathrm{~m}$ of the metalled rural road leading to agricultural production premises. Plot size: width $16 \mathrm{~m}$, length $50 \mathrm{~m}$ (0.08 ha). Altitude: $214-215 \mathrm{~m}$. Topography: flat ground inclined $1^{\circ}$ to SW. Soil type: arenaceous chernozem on non-calcareous aeolian sands.

The TVP 4 is situated in the southern part of the northern section of the biocorridor being intentionally laid out in the vicinity of the Kyjov-Vracov-Veselí nad Moravou main road, more precisely $25 \mathrm{~m}$ north of the road. Plot size: width $16 \mathrm{~m}$, length $50 \mathrm{~m}$ (0.08 ha). 
Altitude: $199 \mathrm{~m}$. Topography: flat ground without obvious ground unevenness. Soil type: arenaceous chernozem on non-calcareous aeolian sands.

\section{Methods}

1) Tree inventory

a) In particular trees, taxonomic classification was carried out.

b)A complete list of determined trees was carried out including their quantitative proportion in 1993-2007.

c) A draft of the tree lay-out was carried out for the expected long-term monitoring of trees.

2) Measuring the basic mensurational parameters at PRP 3 and PRP 4

a) Measuring the tree height (h) in $\mathrm{cm}$ up to the height of $1.5 \mathrm{~m}$, to the height of $8 \mathrm{~m}$ accurate to $5 \mathrm{~cm}$ (or $10 \mathrm{~cm}$ ) and over $8 \mathrm{~m}$ with a minimum accuracy of $0.5 \mathrm{~m}$. A folding $5 \mathrm{~m}$ (later $8 \mathrm{~m}$ ) height-measuring rod was used and a hypsometer Clinomaster.

b) Measuring the perimeter at breast height (dbh) in $\mathrm{mm}$ in trees over $1.3 \mathrm{~m}$ tall or the root collar diameter just above the ground; diameter calculated from the stem perimeter.

c) Determining the crown diameter - measured at 2 directions perpendicular at each other (in non-closed plantations in 1993 - 1996) when $\check{s}_{1}$ was the crown width in the belt direction, $\breve{s}_{2}$ the perpendicular crown width.

These measurements were carried out at all trees on selected PRP. Following taxa of trees were evaluated: Quercus robur (Pedunculate Oak) and Tilia cordata (Small-leaved Linden) as "skeleton" tree species, Acer campestre (Field Maple) and Cerasus avium (Mazzard /Wild/ Cherry) as filling species. Further at shrubs: Swida sanguinea (Dogwood) and Ligustrum ovalifolium (California Privet).

\section{RESULTS AND DISCUSSION}

\section{1) Tree inventory}

\section{PRP 3 (TVP 3)}

Within the tree inventory in PRP 3, the proportion of particular species was determined and evaluated in the period of 1993 - 2007. In total, 19 taxa were determined, see Table 1.

The most abundant species was Ligustrum ovalifolium, namely 95 individuals. During the period of monitoring, the number of the species decreased only by 11 individuals, which represents roughly a $10 \%$ decrease of individuals.

The highest change in the number of individuals during the period under monitoring occurred in Acer campestre, namely from the initial 50 individuals to the present 30 individuals (i.e., a $40 \%$ decrease of individuals). On the other hand, in Swida sanguinea and Prunus spinosa, a negligible increase in the number of individuals occurred thanks to their sprouting capacity. The table also shows the total decrease of trees in PRP 3. From the initial 349 trees in 1993, only 292 individuals were preserved until 2007. 
Table 1: Number of trees in PRP 3 (TVP 3)

\begin{tabular}{|c|c|c|c|c|c|c|}
\hline \multirow{2}{*}{ Species in PRP 3} & \multicolumn{6}{|c|}{ Number of plants in year } \\
\hline & 1993 & 1996 & 1999 & 2002 & 2005 & 2007 \\
\hline Acer campestre-ACC & 50 & 45 & 44 & 32 & 32 & 30 \\
\hline Cerasus avium - CA & 32 & 31 & 29 & 29 & 30 & 29 \\
\hline Carpinus betulus $-\mathrm{CB}$ & 1 & 0 & 0 & 0 & 0 & 0 \\
\hline Corylus avellana - COR & 6 & 6 & 6 & 4 & 4 & 4 \\
\hline Swida sanguinea-COS & 44 & 44 & 43 & 43 & 45 & 47 \\
\hline Juglans regia - JUG & 1 & 1 & 1 & 0 & 0 & 0 \\
\hline Ligustrum ovalifolium - LIGO & 106 & 106 & 106 & 103 & 100 & 95 \\
\hline Ligustrum vulgare - LIGV & 2 & 2 & 2 & 2 & 1 & 1 \\
\hline Lonicera korolkowii - LOK & 1 & 1 & 1 & 1 & 1 & 1 \\
\hline Lonicera tatarica - LOT & 5 & 6 & 6 & 5 & 3 & 5 \\
\hline Padus racemosa $-\mathrm{PAD}$ & 35 & 35 & 35 & 35 & 32 & 31 \\
\hline Populus tremula-POT & 1 & 1 & 1 & 1 & 0 & 0 \\
\hline Prunus spinosa - PS & 3 & 3 & 2 & 2 & 4 & 4 \\
\hline Quercus robur $-\mathrm{QR}$ & 39 & 39 & 36 & 35 & 34 & 33 \\
\hline Rhamnus cathartica - RHC & 5 & 5 & 5 & 5 & 5 & 5 \\
\hline Rosa multiflora-ROM & 4 & 0 & 2 & 2 & 0 & 0 \\
\hline Staphylea pinnata - STA & 4 & 4 & 2 & 0 & 1 & 0 \\
\hline Tilia cordata - TIC & 7 & 7 & 6 & 4 & 4 & 4 \\
\hline Viburnum lantana $-\mathrm{VL}$ & 3 & 3 & 2 & 3 & 3 & 3 \\
\hline Total & 349 & 339 & 329 & 306 & 299 & 292 \\
\hline
\end{tabular}

\section{$\underline{\text { PRP } 4 \text { (TVP 4) }}$}

Within the tree inventory in PRP 4, the number of particular species was determined and evaluated in the period of 1993 - 2007. In total, 15 taxa were determined, see Table. 2.

The most abundant species on this plot (in 1993) similarly to the PRP 3, was Ligustrum ovalifolium, namely 93 individuals. Due to the development of the tree crown layer shading the taxon individuals occurred and so until 2007, their number declined to only three individuals (97\% decrease in the number of individuals). Because it involved an introduced species, which should not be planted in the open landscape, this situation is not really a relevant problem. On the contrary, the spontaneous decline of this species saved financial means, which would be otherwise spent on decreasing their number in the biocorridor.

A significant change in the number of individuals within the monitored period occurred, similarly as in PRP 3, in Acer campestre, namely from the initial 47 to the present 20 individuals (roughly 57\% decline). In this plot, a more sudden total decline of trees occurred with respect to the intense decrease in Ligustrum ovalifolium, i.e. from the 325 individuals in 1993 to the present 180 individuals. 
Table 2: Number of trees in PRP 4 (TVP 4)

\begin{tabular}{|l|c|c|c|c|c|c|}
\hline \multirow{2}{*}{ Species in PRP 4 } & \multicolumn{6}{|c|}{ Number of plants in year } \\
\cline { 2 - 8 } & 1993 & 1996 & 1999 & 2002 & 2005 & 2007 \\
\hline Acer campestre - ACC & 47 & 45 & 41 & 36 & 29 & 20 \\
\hline Cerasus avium - CA & 41 & 41 & 40 & 38 & 38 & 38 \\
\hline Corylus avellana - COR & 7 & 7 & 6 & 7 & 9 & 6 \\
\hline Swida sanguinea - COS & 38 & 38 & 38 & 38 & 38 & 33 \\
\hline Ligustrum ovalifolium - LIGO & 93 & 93 & 83 & 33 & 10 & 3 \\
\hline Lonicera tatarica - LOT & 3 & 3 & 3 & 3 & 3 & 0 \\
\hline Padus racemosa - PAD & 31 & 31 & 33 & 31 & 27 & 28 \\
\hline Populus tremula - POT & 1 & 1 & 1 & 1 & 1 & 1 \\
\hline Prunus spinosa - PS & 3 & 3 & 3 & 3 & 4 & 3 \\
\hline Quercus robur - QR & 38 & 38 & 34 & 34 & 33 & 34 \\
\hline Rhamnus cathartica - RHC & 3 & 3 & 3 & 3 & 1 & 0 \\
\hline Rosa multiflora - ROM & 3 & 0 & 4 & 3 & 2 & 0 \\
\hline Sorbus aucuparia - SOAU & 1 & 1 & 1 & 1 & 1 & 0 \\
\hline Tilia cordata - TIC & 8 & 8 & 8 & 8 & 8 & 8 \\
\hline Viburnum lantana - VL & 8 & 7 & 6 & 6 & 6 & 6 \\
\hline Total & 325 & 319 & 304 & 245 & 210 & 180 \\
\hline
\end{tabular}

\section{2) Evaluation of mensurational parameters}

\section{PRP 3}

\section{Height}

In 1993 - 1996, in the initial stage of the tree layer development, the height was measured annually. The main "skeleton" species Quercus robur reached a mean height of $132.9 \mathrm{~cm}$ in 1993 . In the following years, the mean height gradually increased to $566 \mathrm{~cm}$ (1999) and $738 \mathrm{~cm}$ (2005). In 2007, the last measurement was carried out and Quercus robur reached a mean height of $804 \mathrm{~cm}$, see Table 3 .

The tallest Quercus robur measured $270 \mathrm{~cm}$ in 1993, six years later then $700 \mathrm{~cm}$. At the last measurement in 2007, the tallest Quercus robur reached $993 \mathrm{~cm}$.

Mean heights of Quercus robur are given in Fig. 1 compared with the height growth of Acer campestre, Tilia cordata and Cerasus avium. 
Table 3: Biocorridor Vracov, mean parameters of monitored species in 2007

\begin{tabular}{|l|c|c|c|c|c|c|c|c|}
\hline \multirow{2}{*}{ Species } & \multicolumn{4}{|c|}{ PRP 3 } & \multicolumn{4}{c|}{ PRP 4 } \\
\cline { 2 - 9 } & $\begin{array}{c}\text { Mean } \\
\text { height } \\
(\mathrm{cm})\end{array}$ & $\begin{array}{c}\text { Standard } \\
\text { deviation } \\
(\mathrm{cm})\end{array}$ & $\begin{array}{c}\text { Mean } \\
\mathrm{dbh} \\
(\mathrm{cm})\end{array}$ & $\begin{array}{c}\text { Standard } \\
\text { deviation } \\
(\mathrm{cm})\end{array}$ & $\begin{array}{c}\text { Mean } \\
\text { height } \\
(\mathrm{cm})\end{array}$ & $\begin{array}{c}\text { Standard } \\
\text { deviation } \\
(\mathrm{cm})\end{array}$ & $\begin{array}{c}\text { Mean } \\
\text { dbh } \\
(\mathrm{cm})\end{array}$ & $\begin{array}{c}\text { Standard } \\
\text { deviation } \\
(\mathrm{cm})\end{array}$ \\
\hline Acer campestre & 687 & 13.5 & 8.2 & 3.2 & 905 & 13.7 & 8.8 & 3.6 \\
\hline Cerasus avium & 770 & 64.2 & 12.5 & 9.79 & 1,330 & 200.8 & 19.3 & 5.82 \\
\hline Quercus robur & 804 & 100.1 & 10.7 & 6.21 & 1,566 & 367.9 & 14.0 & 4.30 \\
\hline Tilia cordata & 810 & 52.3 & 13.4 & 4.52 & 1,659 & 346.9 & 16.9 & 4.09 \\
\hline
\end{tabular}

Fig. 1: PRP 3 Vracov, mean heights of Acer campestre, Cerasus avium, Quercus robur and Tilia cordata

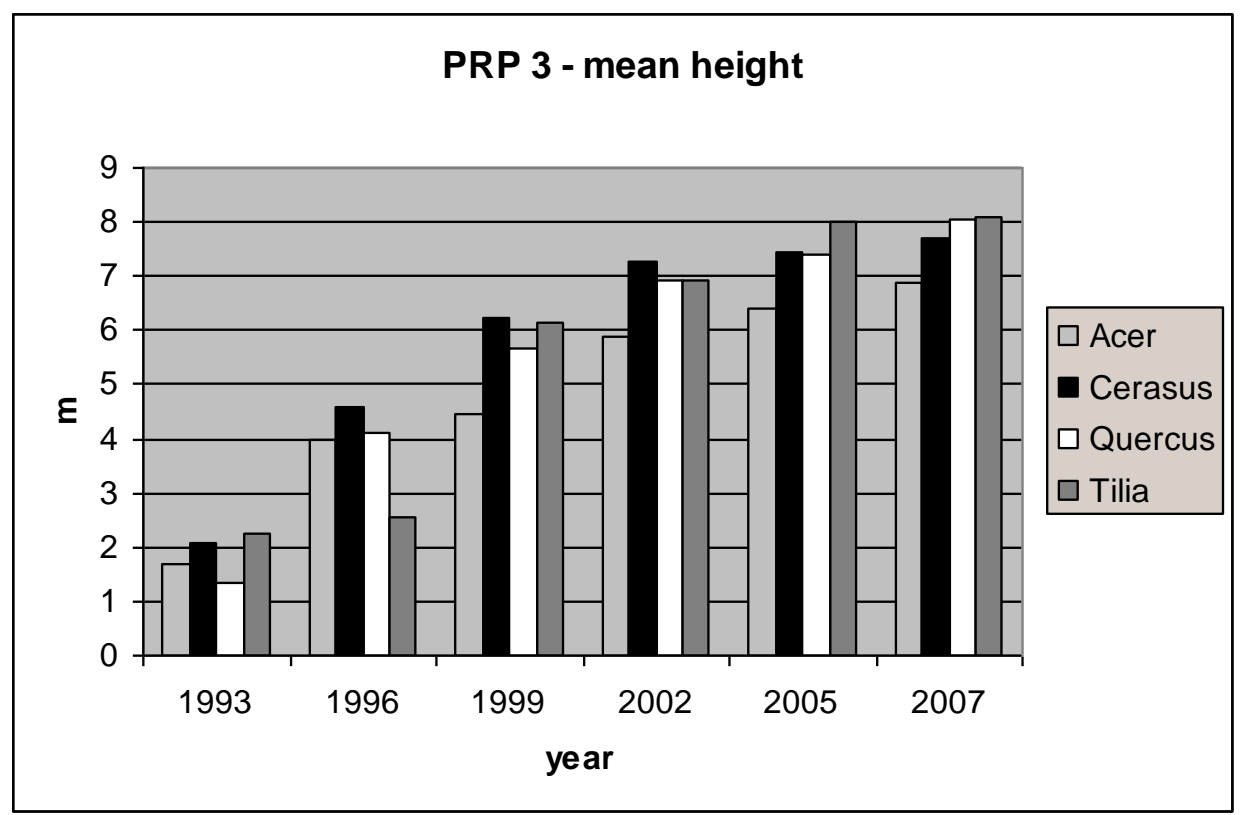

Unlike Quercus robur, Tilia cordata was planted out as a sapling with a trained crown. During a several-year period, $T$. cordata demonstrated only minimum growth (due to a post-planting shock). After the initial stagnation, the height increment of $Q$. robur and $T$. cordata does not differ significantly. In 2007, the mean height of lime trees was $810 \mathrm{~cm}$ (of oaks $804 \mathrm{~cm}$ ). The highest individual of T. cordata in PRP 3 reached $900 \mathrm{~cm}$ in 2007.

The most abundant filling species is Cerasus avium. The species demonstrated bigger height increment compared with oak at the beginning of the monitoring period. Its mean height reached $207.4 \mathrm{~cm}$ in 1993 and $621.6 \mathrm{~cm}$ (1999). In recent years, this trend was stopped and Cerasus avium reached a mean height of $743.7 \mathrm{~cm}$ in 2005 . At the last measurement in 2007, its mean height was $770 \mathrm{~cm}$. The tallest individual reached $933 \mathrm{~cm}$.

In 2007, the mean height of Acer campestre was lower by more than $2 \mathrm{~m}$, namely 686.5 $\mathrm{cm}$. 
The mean height of shrub species Ligustrum ovalifolium and Swida sanguinea can be characterized by values 334.7 or $260.8 \mathrm{~cm}$, which were reached in 1996. At present, in the period of the last measurement, the mean height was 408.2 or $341.2 \mathrm{~cm}$.

\section{Diameter at breast height (dbh)}

Cerasus avium was a species with the highest increase of the $d b h$ values during the whole period of monitoring. Its diameter dimensions in particular years at the beginning of the research reached $15.3 \mathrm{~mm}$ (1993), $101.2 \mathrm{~mm}$ (1999) and $119.0 \mathrm{~mm}$ (2005). At the last measurement, its mean diameter reached $12.5 \mathrm{~cm}$, in a tree of the largest diameter then 17.7 $\mathrm{cm}$. The second species with the highest mean increment was Quercus robur (the main skeleton species), which reached the mean $d b h$ of $72.1 \mathrm{~mm}$ in $1999,10.2 \mathrm{~cm}$ in 2005 and $10.7 \mathrm{~cm}$ in 2007. A species with the highest mean $d b h$ was Tilia cordata $-13.4 \mathrm{~cm}$ in 2007 , see Fig. 2. The last species, where the mean values of mensurational characteristics mentioned above were assessed, was Acer campestre, which reached the $d b h$ of $9.9 \mathrm{~mm}$ (1993) or $82 \mathrm{~mm}$ (2007).

Fig. 2: PRP 3 Vracov, mean $d b h$ in Acer campestre, Cerasus avium, Quercus robur and Tilia cordata

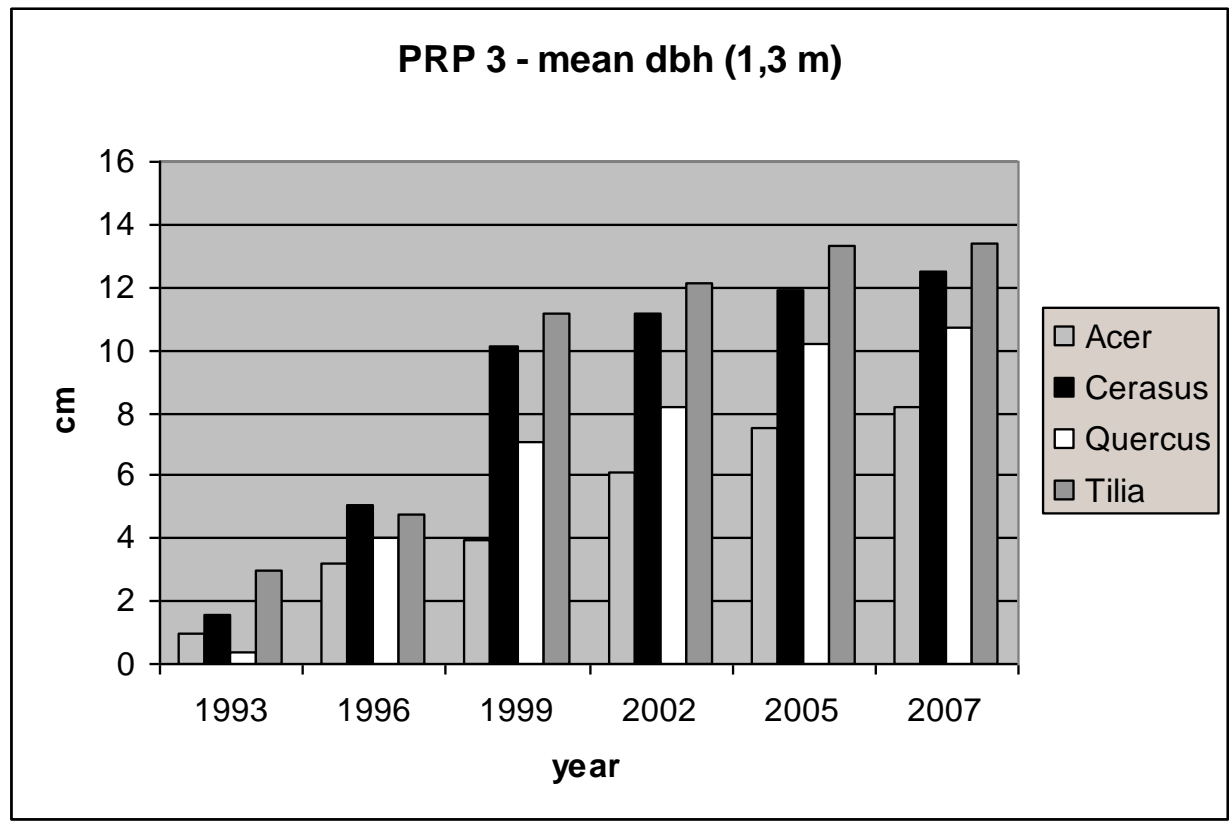

\section{Crown width}

Development of the mean size of the crown of the most frequent representative of the tree layer in PRP 3 (Acer campestre) is characterized by following width parameters: $126.4 \mathrm{x}$ $139.1 \mathrm{~cm}$ (1993), $189.1 \times 213.9 \mathrm{~cm}$ (1994), 225.7 x $254.1 \mathrm{~cm}(1995)$ and 236.5 x $253.8 \mathrm{~cm}$ (1996).

The main skeleton species Quercus robur in the monitored plot increased the width of its crowns during the three years roughly 3.6 times reaching the following values in particular years: 46.2 x $52.4 \mathrm{~cm}$ (1993), 115.3 x $118.1 \mathrm{~cm}$ (1994), $142.2 \times 177.7 \mathrm{~cm}$ (1995) and 166.5 $\mathrm{x} 192.8 \mathrm{~cm}$ (1996). Padus racemosa reached regularly the highest mean values of the 
monitored quantity (244.6 x $295.9 \mathrm{~cm}$ in 1996). The width of crowns of the remaining species determined by measurements in 1996 was 250.2 x $266.2 \mathrm{~cm}$ in Cerasus avium, 187.5 x $233.9 \mathrm{~cm}$ in Ligustrum ovalifolium and 160.0 × $203.4 \mathrm{~cm}$ in Swida sanguinea.

A gradual development of the crown canopy of monitored species occurred in the following years.

\section{PRP 4}

\section{Height}

The mean height of Quercus robur demonstrating the height increment of main skeleton species reached $145.2 \mathrm{~cm}$ (1993), $377.6 \mathrm{~cm}$ (1996) and $610.5 \mathrm{~cm}$ (1999) at the beginning of the research period.

In $2005, Q$. robur reached the mean height of $1,028.8 \mathrm{~cm}$ and $1,566 \mathrm{~cm}$ in 2007 , see Fig. 3.

Fig. 3: PRP Vracov 4, mean heights of Acer campestre, Cerasus avium, Quercus robur and Tilia cordata

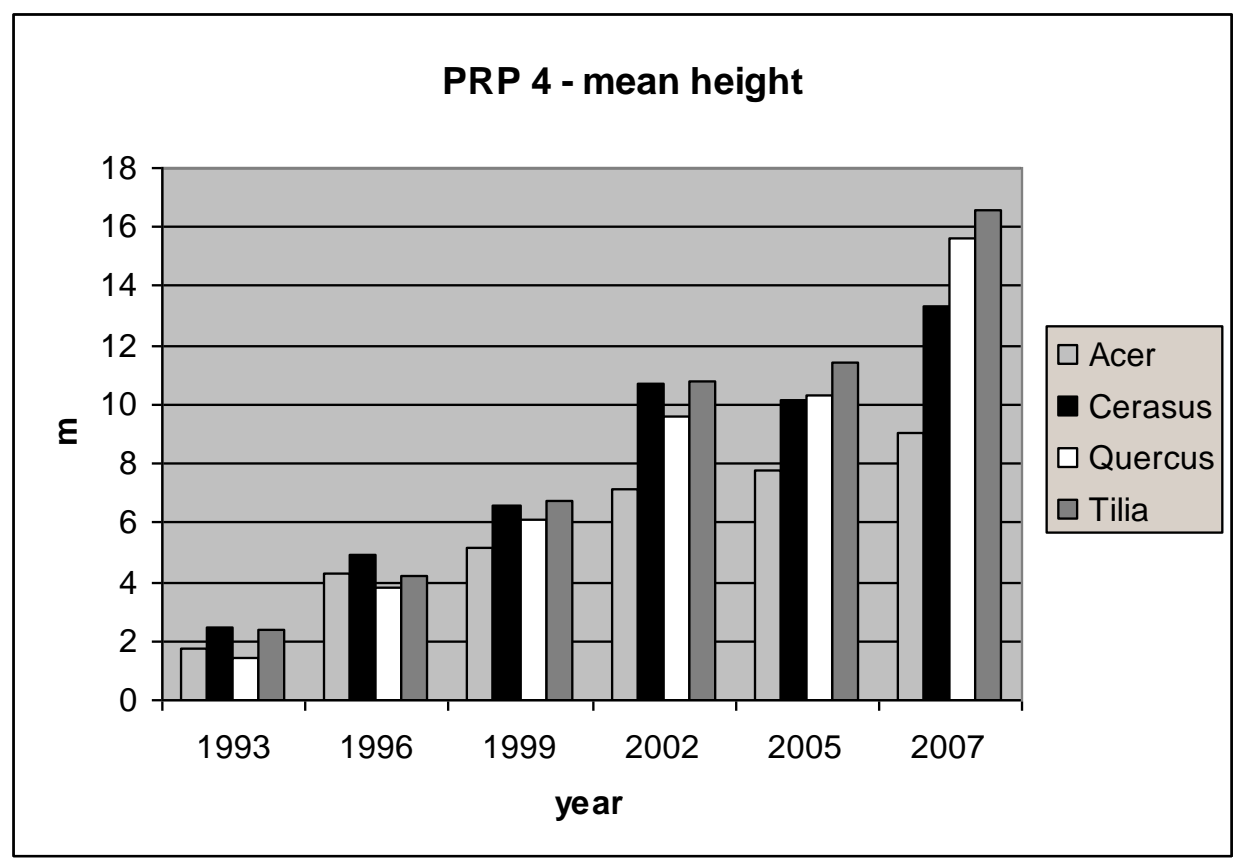

The tallest Quercus robur measured in 1993 reached $270 \mathrm{~cm}$, six years later then $720 \mathrm{~cm}$. At the last measurement in 2007, the tallest oak reached 2,140 cm.

The second main skeleton species - Tilia cordata reached the mean height of $234.9 \mathrm{~cm}$ (in 1993), $673 \mathrm{~cm}$ (1999) and 1,138 cm (2005). At the last measurement carried out in 2007, the mean height determined in Tilia cordata was $1,659 \mathrm{~cm}$ the tallest individual reaching 2,090 cm.

The most abundant arborescent species Cerasus avium (a filling species) displayed a mean height of $248.7 \mathrm{~cm}$ in 1993. In the following years, the mean height reached $656.6 \mathrm{~cm}$ in 1999 and $1,015 \mathrm{~cm}$ in 2005. At the last measurement, which was carried out in 2007, the mean height of $1,330 \mathrm{~cm}$ was obtained, see Table 3 . 
Acer campestre reached the mean height of $904.5 \mathrm{~cm}$ in 2007, i.e. roughly $7 \mathrm{~m}$ less than the main skeleton species.

The mean height of shrub species Ligustrum ovalifolium and Swida sanguinea can be characterized by values 150.3 or $116.1 \mathrm{~cm}$ reached in 1993 . At present, at the last measurement, their mean height was $306.7 \mathrm{~cm}$ or $472.4 \mathrm{~cm}$ respectively.

\section{Diameter at breast height (dbh)}

The highest mean $d b h$ was regularly shown by Cerasus avium (except the saplings of Tilia cordata) where the stem diameter in particular years was $21.5 \mathrm{~mm}(1993)$ and $10.9 \mathrm{~cm}$ (1999). In 2005, it was already $17.5 \mathrm{~cm}$ and in 2007 the $d b h$ reached $19.3 \mathrm{~cm}$. In 1993, the main skeleton species Quercus robur showed the $d b h$ of $20.0 \mathrm{~mm}$. In the following years, the $d b h$ of $Q$. robur developed as follows: in 1996 it amounted to $75.5 \mathrm{~mm}$ and in 200512.3 $\mathrm{cm}$. At the last measurement (in 2007), the mean $d b h$ amounted to $14.0 \mathrm{~cm}$.

The second main skeleton species - Tilia cordata displayed a good diameter increment in PRP 4. In 1993, the mean $d b h$ was $40.4 \mathrm{~mm}$ and in $199912.2 \mathrm{~cm}$. In 2005, T. cordata already reached the mean $d b h$ of $16.4 \mathrm{~cm}$. At the last measurement (in 2007), the mean $d b h$ reached $16.9 \mathrm{~cm}$, see Fig. 4.

A species with the highest mean $d b h$ (Cerasus avium $-19.3 \mathrm{~cm}$ ) occurred also in PRP 4 in 2007. The last species, the mean dbh of which was assessed, was Acer campestre reaching the value of $88.2 \mathrm{~mm}$ (2007), see Table 3 .

Fig. 4: PRP 4 Vracov, mean $d b h$ in Acer campestre, Cerasus avium, Quercus robur and Tilia cordata

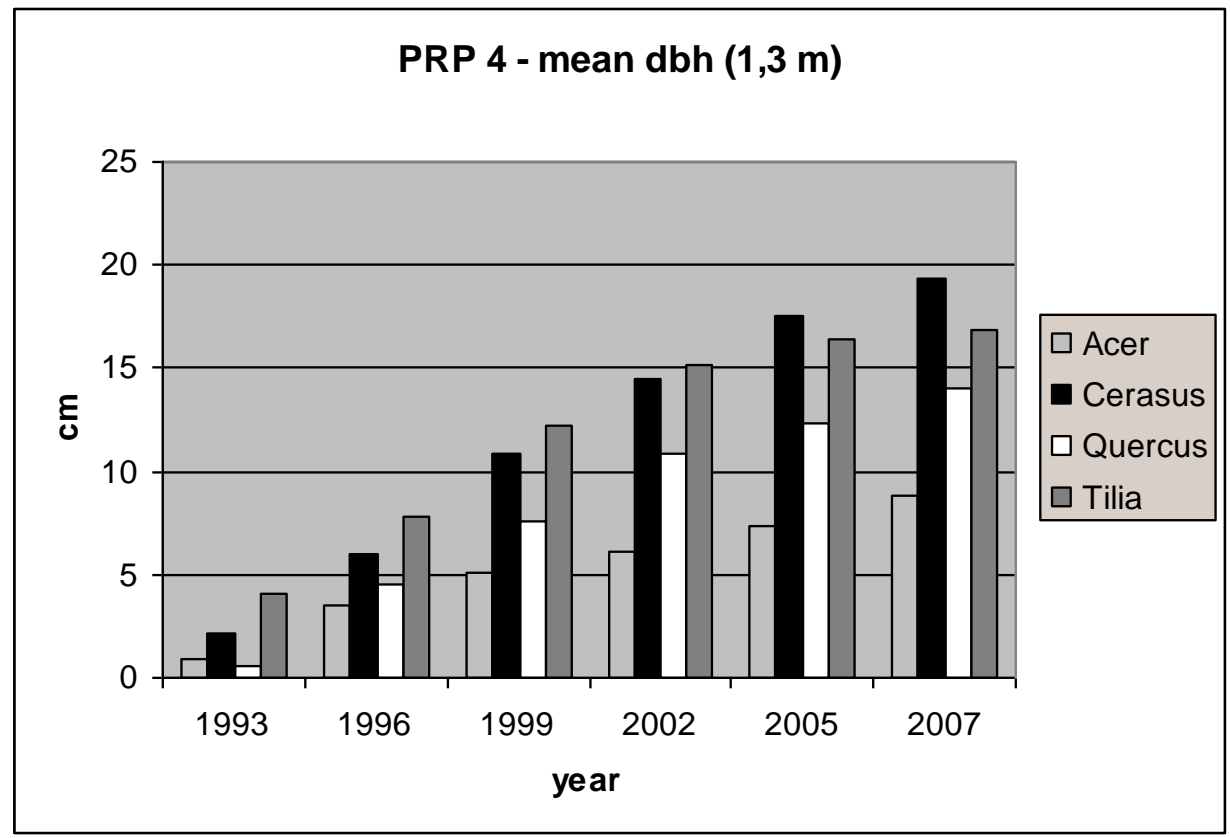

\section{Crown width}

Throughout the monitoring of the dynamics of the gradually increasing crown projections of selected tree species mentioned below it has been found out that the crown width of the main skeleton species Quercus robur increased on average 2.4 times within three years. 
From the initial $89.8 \times 95.0 \mathrm{~cm}$ in 1993 it increased to $232.0 \times 211.5 \mathrm{~cm}$ in 1996 . Another significantly represented species, Cerasus avium, increased the mean width of its crown from 19931.8 times and in 1996, its crown projection was $244.1 \times 299.6 \mathrm{~cm}$.

A filling species, Acer campestre, showed the crown width of $236.3 \times 272.8 \mathrm{~cm}$ at measurements in 1993. In shrubs Swida sanguinea and Ligustrum ovalifolium, these dimensions were $177.1 \times 204.1 \mathrm{~cm}$ or $150.3 \times 193.2 \mathrm{~cm}$ in 1996 , i.e. 1.9 times increase comparing to the situation in 1993.

As already mentioned in PRP 3, the canopy closure of monitored species occurred in the following years. Due to the penetration of branches (in both PRP) the insufficiently illuminated parts of crowns died. The crown projection does not significantly increase any more and a reduction of the area covered by the crowns occurs. This process is evident particularly in shrubs in the edge rows of the biocorridor. The shrubs (in consequence of shading) show considerably developed asymmetric crown. With respect to the gradual development of canopy closure in the biocorridor, a successive decrease in the numbers of individuals on particular research plots occurs (in spite of a temporary increase in 1996). Sprouts and seedlings of species growing in the biocorridor were observed in the understorey.

Mean values of monitored parameters were always higher in all trees comparing to the PRP 4. It is probably caused by the higher amount of available moisture in soil. Nearly identical $d b h$ values in both PRPs were measured in Acer campestre, which achieved the values of 82 and $88 \mathrm{~mm}$ in 2007. Nevertheless, as for height, mean values differ in this taxon by more than $2 \mathrm{~m}$ on particular plots. Crowns of all species mentioned above with the exception of Quercus robur were remarkably asymmetric, their width being usually greater comparing to the belt direction, i.e. trees in this early stage of development use more space between particular rows.

Particularly Cerasus avium thrived well as a filling species reaching similar parameters on both plots as the skeleton species Quercus robur and Tilia cordata.

\section{CONCLUSION}

Based on the results obtained we can state that species of the biocorridor tree layer grow very well. Although the number of individuals gradually decreases, their number is sufficient the successful development of a forest community to be guaranteed.

The noted reduction of the shrub layer trees in the biocorridor inner part does not display a fundamental effect on its further development and function. Thus, mean heights and $d b h$ reached in particular trees can be evaluated positively. Cerasus avium thrived very well under the given conditions. The species appeared to be very perspective not only from the aspect of biomass creation but also the subsequent quality and utilization of wood.

Because there are no sufficient data in literature on the growth of the tree species on agricultural land, it is virtually impossible to compare the results obtained. Also in forestry practice, attention is not paid to the evaluation of the growth of young plantations. Therefore, the results obtained can be evaluated for guidance, as a material for further comparisons in the future. Perhaps, it will be possible to use the findings obtained in the construction of growth models at the early stage of the plantation development. Thus, this paper contributes to the further knowledge of tree prosperity and growth on former agricultural land. 


\section{ACKNOWLEDGEMENT}

This project was supported by the Ministry of Education of the Czech Republic, project MSM 6215648902 and by IGA, project 12/2010.

\section{REFERENCES}

Bennett, A. F. (2003). Linkages in the landscape: The role of corridors and connectivity in Wildlife conservation, IUNC, Gland, Switzerland and Cambridge, $254 \mathrm{pp}$.

Bennett, G. (2004). Linkages in Practice: a Review of Their Conservation Practice. IUCN, Gland, Switzerland and Cambridge, $28 \mathrm{pp}$.

Buček, A., Lacina, J. (1984). Biogeographical approach to the creation of territorial systems of landscape ecological stability. Zprávy Geografického ústavu ČSAV Brno, 21/4 :27-35 pp.

Buček, A., Lacina, J. \& Míchal, I. (1995). An Ecological Network in the Czech Republic. Veronica, Vol. 10, special issue, Brno, 44 pp.

Fabos, J. G., Ahern, J. F. (1996). Greenways: The Beginning of an International Movement, Elsevier, $491 \mathrm{pp}$.

Hilty, J. A.; Lidicker, W. Z.; Merenlender, A. M. \& Dobson, A. P. (2006). Corridor Ecology: The Science and Practice of Linking Landscapes for Biodiversity Conservation, Island Press, Chicago, 323 pp.

Jongman, R. H. G.; Pungetti, G. (2004). Ecological networks and greenways: concept, design implementation (Cambridge Studies in Landscape Ecology), Cambridge University Press, Cambridge, 345 pp.

Löw, J. (1995). Rukovět’ projektanta územního systému ekologické stability. MŽP a Löw a spol., Brno, 122 pp.

Selucký, Z. (2008). Dendrologicko - ekologické hodnocení biokoridoru Vracov, bakalářská práce, Mendelova zemědělská a lesnická univerzita v Brně, Brno.

Úradníček, L. (2001). Hodnocení dřevinné složky biokoridorů. Závěrečná zpráva 2001, Brno, 17 pp.

Úradníček, L. (2002). Hodnoceni růstu dřevin v biokoridoru Vracov (Woody species growth evaluation in biocorridor Vracov). In: Maděra, P. (ed.): Ekologické sítě. Sborník př́spěvků z mezinárodní konference 23.-24.11. 2001 v Brně, Geobiocenologické spisy, sv.6, MZLU Brno.

Úradníček, L. (2004). Evaluation of the Woody Component Development of the Model Biocorridor. Ekológia, Bratislava, Vol. 23, Supplement 1:351-361, SAV Bratislava, ISSN 1335-342X.

Zimová, E. (2002). Zakládání místních územních systémů na zemédělské pưdě, Mze Praha, Lesnická práce, Kostelec n. Č. lesy, 52 pp . 